\title{
Social Risks as the Source of Threats and Concerns: The Survey in the Czech Republic
}

\author{
Ludmila Siarda Trochtová ${ }^{1, *}$, Jiř́ Pospíšil ${ }^{2}$ and Helena Pospíšilová ${ }^{2}(\mathbb{C}$ \\ 1 Department of Christian Education, Palacký University, 77900 Olomouc, Czech Republic \\ 2 Department of Christian Social Work, Palacký University, 77900 Olomouc, Czech Republic; \\ jiri.pospisil@upol.cz (J.P.); helena.pospisilova@upol.cz (H.P.) \\ * Correspondence: ludmila.trochtova@upol.cz
}

Citation: Trochtová, L.S.; Pospíšil, J.; Pospíšilová, H. Social Risks as the Source of Threats and Concerns: The Survey in the Czech Republic. Societies 2021, 11, 139. https:// doi.org/10.3390/soc11040139

Academic Editor: Lucie Vidovićová

Received: 12 August 2021

Accepted: 24 November 2021

Published: 26 November 2021

Publisher's Note: MDPI stays neutral with regard to jurisdictional claims in published maps and institutional affiliations.

Copyright: (c) 2021 by the authors. Licensee MDPI, Basel, Switzerland. This article is an open access article distributed under the terms and conditions of the Creative Commons Attribution (CC BY) license (https:// creativecommons.org/licenses/by/ $4.0 /)$.

\begin{abstract}
The object of this research was to determine the subjective recognized social threats in the context of contemporary society. Given the growing number of people who feel threatened by certain social threats, there is a presumption that the risk is real, and the identified groups are affected by social risks. The recognition of social threats in the population has a broader social context, and may be influenced by key socio-demographic factors. This influence is significant for many risks, and helps to better understand the nature of the specific groups at risk. It also allows us to recognize that the socio-demographic and family context creates specific conditions for the occurrence of social threats. The aim of the paper is to find the relationships between different types of social threats and gender, age groups, personal situation (occupation), educational attainment, and family situation. A similar study was carried out by the OECD in 2018 (the Czech Republic was not included). The research was designed as cross-sectional ex-post-facto, and the statistical significance was determined using $\chi 2$ test of independence. The survey was carried out in 2018-2019 nationwide across the Czech Republic. The processed data of 5425 respondents has shown that, in the Czech Republic, the subjectively perceived significant threats seem to be the loss of job and unemployment, insufficient skills, and an unwillingness to educate oneself or to be trained, social pressure, and unsatisfactory housing conditions. The research reveals that the recognition of social threats depends on social and family conditions, and there exist specific groups feeling threats more intensively than exist in others. The groups that are at the most risk are individuals with primary education and an apprenticeship. In the population, women are more at risk, as well as the 25-34 and 45+ age groups.
\end{abstract}

Keywords: social risks; social threats; unemployment; social pressure; unsatisfactory housing conditions

\section{Introduction}

Globalization, and demographic and climate change provide new opportunities for growth, but they also increase the risk of widening inequalities [1,2]. Social risks in today's society, especially the newly emerging ones, are subject to intensive research [3-5]. Contrary to common social risks, the new social risks affect a much wider spectrum of society.

The object of the published research was to determine the subjective perceived social threats in the context of contemporary society. Given the growing number of people who feel threatened by certain social threats, there is a presumption that the risk is real, and the identified groups are affected by social risks. The recognition of social threats in the population has a broader social context, and may be influenced by key socio-demographic factors. The aim of this study was to find relationships between different types of social threats and gender, age groups, personal situation (occupation), educational attainment, and family situation.

This study builds on previous partial research on social risks in the Czech Republic, and reports on a more extensive investigation of these risks in 2018 and 2019; the questionnaire survey was also inspired by a similarly focused OECD study from 2018, which did not 
include the Czech Republic. The Organization for Economic Cooperation and Development $(\mathrm{OECD})$ is an international organization that unites 34 of the most economically developed countries in the world. The aim of the OECD study [6] was to identify the concerns of people throughout the countries. The OECD survey examined the perception of social and economic risks, and addressed 22,000 adults (aged 18-70) in 21 countries in the spring and autumn of 2018. The Czech Republic has been a member of the OECD since 1995, when it was received as the first country of the post-communist states, but it did not participate in the above-mentioned research. Therefore, we extended our long-term survey, focusing primarily on the area of values and free time, with the dimension of social risks depending on other social determinants (gender, age, occupation, family condition, education).

The new social risks are the result of socioeconomic changes linked to the transition to a post-industrial society $[7,8]$. According to Bonoli [7] new social risks could be divided into the following categories: the necessity to harmonize family life and a work life, existence of incomplete families, care of the ill and of elderly members of the household, insufficient work skills, and insufficient insurance, especially when people are old. The family pillar of the social system is failing more and more often, and results in the overburdening women who are not able to harmonize the requirements of the employer with looking after their children, ill members of the family, and/or their own parents. Another consequence of this is the rising number of incomplete households, consisting mainly of single parents (women) and their children. The result of the failure of the labor market pillar is that it is more and more difficult for young people to get their first job, as well as for older employees to keep their job until they retire. Moreover, it did not guarantee that the executed work was interconnected with the insurance systems (e.g., serious illness). Privatization of insurance systems is another source of social risks. Their individualization and the accompanying desolidarization of the insured person makes it difficult to insure individuals during particular phases of their life, especially in phases of economic inactivity of the individual [9].

These new social risks occur a result of modern society changes in economic, demographic, and social structures, and they are also the result of the fact that the main support from the social security system, i.e., the welfare state, labor market, and family; these began failing as the safeguards, and became the sources of the new insecurities [9].

Taylor-Gooby [8] points out four procedures that had the main role in the postindustrial society, i.e., the transfer of a huge number of women into the labor market, an increase in the number of older people who need social care, changes in the labor market that are linked to the technical progresses and emphasized education, and the widening private social care services which helps reduce government expenditure.

Contrary to the issues of poverty and social class inequalities that welfare states were able to cope with in various ways before, the new risks are a challenge for a wide and drastic reform or transformation of the social and social-political institutions in a modern society $[9,10]$.

Klimplová [11] examined new social risks in central and eastern European countries in the transition from centrally planned to market economies. These include a rise in the number of unemployed persons, a significant decline in the agricultural and industrial workforce, the formation of a new managerial elite (class), the abandonment of lifetime employment status (for more flexible employment contracts), a decline in fertility rates, an ageing population, fewer marriages, higher divorce rates, and increasing poverty among both single parents with children and households with multiple children. Our research did not cover all of these threats, but indeed confirmed many of them. Threats to the state of the Czech family were more fully addressed in research carried out by the Sirius Foundation [12], which found that $55 \%$ of ordinary families with children have a loan or are in debt. In families with one biological parent, the vast majority of households have difficulty making repayments, with $47 \%$ having great difficulty. The accumulation of loans and the extent of liabilities that do not match household income which then manifested in 
foreclosures and threats from debt collectors are a threat to household economic stability, as confirmed by our research.

In the population of the Czech Republic, women are traditionally slightly prevalent. At the end of 2018, the female proportion of the population was 50.8\% (5.41 million inhabitants), and the male proportion was $49.2 \%$ (5.24 million people) [13]. According to Eurostat [14], in December 2018, the employment rate of individuals in the 15-64 age group in the Czech Republic was $75.4 \%$ (82.2\% for men, and $68.4 \%$ for women). In 2018, $7 \%$ of employees in the 15-64 age group had a definite term contract, and were at risk of non-renewal of their work contract by the employer. In 2018, the unemployment rate in the Czech Republic was 2.2\%, and is one of the lowest among all 28 EU member states [13].

The unemployment rate of people with primary or lower secondary education was $9.4 \%$ in 2018 [14]. In terms of education, individuals with primary education feel threatened by risk of unsatisfactory housing conditions. Individuals with apprenticeships also feel at risk of unsatisfactory housing conditions, but also of loss of housing, due to a lack of financial funds and loss of housing for other reasons, e.g., lease termination by the leaser, graduation, transitioning to another job, loss of job and unemployment, insufficient skills, as well as the unwillingness to be further educated or trained, high debt burden and attachment of earnings, and the associated threat by debt collectors. The unemployment rate of people with higher secondary education and follow up education was $1.9 \%$ in 2018 [14]. Both of these categories seem to be very vulnerable to the potential of threats. There are efforts to compel these individuals get further education and improve their education and consequently their employment opportunities. The threat did not appear in the category of individuals with tertiary education. The unemployment rate of people with tertiary education was $1.1 \%$ in 2018 [14].Lower skills of women in comparison with men manifested especially in individuals with primary education, as well as in individuals with tertiary education, where a lower remuneration is apparent. Now, young women overcome this difference by receiving further education [15].

Individuals who live in an incomplete family with their parents without a family started of their own feel threatened by unsatisfactory housing conditions. Moreover, they strongly experience social pressure from the family, relatives, and close ones, etc.; they also admit a risk of oppression, pressure, blackmailing, or threats from adults in the workplace, as well as a lack of financial funds for further education. In the Czech Republic, there was an important decrease, both absolute and relative, in the number of divorces of couples with minors. According to the data of the Ministry of Justice, in 2018, there were 14,193 marriages with young children which ended in divorce (1000 less than in 2017), and 10,120 marriages without young children which ended in divorce (400 less year-on-year). Nevertheless, divorces of marriages with minors constituted $58.4 \%$ of the total number of divorces in 2018 [13]. With regards to divorces with marriages lasting 25 years or more, $86 \%$ of them were without young children in 2018. Divorces without young children also prevail, concerning the shortest durations of marriages ( $54 \%$ among divorces of marriages lasting less than 5 years) [13].

Previous research has indicated that the recognition of social threats in the population has a wider social context, and could be influenced by crucial sociodemographic factors such as gender, age, achieved education, personal situation (occupation), and family situation. It seems to us that this influence is significant, which helps us to understand these specific groups in risk and the essence of subjective threat recognition better. It allows us to make a theoretical assumption that the sociodemographic and family context creates the specific conditions influencing the social threats recognition.

The aim of the survey was to confirm the theoretical assumption mentioned above by finding possible connections between the socio-demographic factors and individual types of social threats. Consequently, we can assume that respondents who feel at risk of some of the social threats are a potential risk group that is particularly concerned about the new social risks. To be able to carry out the survey, it was necessary to select the tools to 
measure the individual social categories, as well as to identify individual social threats to the respondents.

\section{Materials and Methods}

To confirm the theoretical assumption that the subjective recognition of social threats influenced by social and family context, we planned and conducted a nationwide survey. The research was designed as cross-sectional ex-post-facto. This approach used often to measure and analyze inferences of the social factors on specific phenomena [16,17]. The survey was carried out nationwide across the Czech Republic. The examined context was part of a wider examination Research of Values, Key Worldview Questions, Leisure, Social Threats and ICT Skills 2018, focusing, besides social threats, on the value orientation of the respondents, their economic situation, and ways of spending their free time. The survey examined data collected using a structured questionnaire, which was completed and returned from a total of 5425 respondents aged 15+ selected from the entire population of the Czech Republic. Their stratification details can be found below in Section 2.1. The data was collected via a questionnaire (both electronic and printed) from September 2018 to June 2019. The survey was delivered both electronically and using a hard paper copy. In the case of respondents who were not able to fill out the questionnaire online, in person interviews or assisted completion of the questionnaire was utilized. Due to the method for the data collection and the saving of the results on the database, we are unable to differentiate between online or paper assisted results, which is the reason why we cannot test the differences in collection methods. However, the hard paper copies did not exceed $10 \%$ of questionnaires collected. The respondents were selected across the country using a stratified selection with stratification criteria gender, age, and size of the municipality. Within the stratified groups, the questionnaire widely and randomly spread across the population, thanks to more than 200 volunteers helping to deliver the survey. The collected data can be considered representative of the gender and age of respondents and size of the municipality -in most of the stratification criteria, the difference between population and samples in stratification criteria was less than $10 \%$.

\subsection{Measuring the Basic Social Categories}

In the survey, the basic factors $(\mathrm{F})$ influencing the social threats were identified as follows: gender; age; family conditions; education; and occupation. These variables were non-manipulatable (independent) [16].

Gender $\left(\mathrm{F}_{1}\right)$ was identified by using a categorical closed scale consisting of the following categories: man $(2319 ; 42.75 \%)$; woman $(3090 ; 56.96 \%)$; and other $(16 ; 0.29 \%)$. Considering the marginal number of respondents who identified themselves with the category "other gender", and the statistical inconclusiveness of this category, we had to exclude this category from our statistical analyses, regardless of how much the relevant analyses could enrich the connections examined by our research.

The respondents' age $\left(\mathrm{F}_{2}\right)$ was measured by using an open answer, and, consequently, age categories of 10-year lengths were created for the purposes of the survey: 15-24 (1443; $26.60 \%)$; 25-34 (1194; 22.01\%); 35-44 (1020; 18.80\%); 45-54 (857; 15.80\%); 55-64 (476, 8.77\%); and $65+(423,7.80 \%)$. Twelve respondents $(0.22 \%)$ did not state their age.

Aside from the age and gender, this was the third stratification criterion supporting the sample to be representative. In our sample, there were respondents from small villages (<2000 habitants, 1241, 22.88\%), bigger villages (2001-5000 habitants, 696, 12.83\%), small towns (5001-15,000 habitants, 898, 16.55\%), towns (15,000-60,000 habitants, 1223, $22.54 \%)$, cities $(60,001-150,000$ habitants, $636,11.72 \%)$, and big cities $(>150,000$ habitants, $731,13.47 \%)$.

Occupation $\left(\mathrm{F}_{3}\right)$ was measured by using a closed categorical scale with the following categories: pupil/student (1126; 20.76\%); employed (3068; 56.55\%); self-employed (412; $7.59 \%)$; pensioners, disabled pensioners, and parental leave $(764 ; 14.08 \%)$; and unemployed $(55 ; 1.01 \%)$. 
Family conditions were $\left(\mathrm{F}_{4}\right)$ divided into eight sub-categories. Respondents are living (a) with their parents in a complete family without a family started on their own (1022; $18.84 \%$ ); (b) with their parents in an incomplete family without a family started on their own $(297 ; 5.47 \%)$; (c) with their grandparents, foster parents, or in a children's home $(44 ;$ $0.81 \%)$; (d) alone and/or other $(741 ; 13.66 \%)$; (e) with a partner, married $(1063 ; 19.59 \%)$; (f) with a partner, unmarried $(844 ; 15.56 \%)$; $(\mathrm{g})$ in a complete family started on their own and with children $(1204 ; 22.19 \%)$; (h) in an incomplete family started on their own and with children $(210 ; 3.87 \%)$.

The last category of the highest achieved level of education $\left(\mathrm{F}_{5}\right)$ included four subcategories: primary education (579; 10.67\%); apprenticeship (780; 14.38\%); secondary education (2290; 45.21\%); and tertiary education $(1776 ; 32.74 \%)$.

\subsection{Identification of Social Threats in the Survey}

From a methodological point of view, measuring social threats $(\mathrm{T})$ is a problem, as these facts cannot be validly measured by direct questioning. Therefore, for the purposes of the survey, we did not go for the measurement of the social threat itself, but we used a subjective perception of the existence of the social threat from the respondent's point of view. This method of measurement was tested in our pilot study [18]. We assumed that people, who subjectively identify a threat, create a subset of people who are really at risk by these threats. We came to such an assumption mainly due to the fact that the current personal situation of the respondent in many cases is not so clear. Nevertheless, the existence of the threat could be perceived as a current or even potentially a future threat by the respondent. The examined risks are especially those that meet the following criteria: (1) it is a threat described and discussed in the current scientific literature; (2) it is a threat that significantly affects the quality of life of the respondents or their household members; and (3) it is a threat which, if fulfilled, leads to shifts of the value orientation of the respondent.

Therefore, the field of measurement of respondent's social risks was examined by asking questions with binomial answers (yes/no) that related to unsatisfactory housing conditions $\left(\mathrm{T}_{1} ; 309 ; 5.70 \%\right)$, loss of housing due to lack of financial funds $\left(\mathrm{T}_{2} ; 259 ; 4.77 \%\right)$, loss of housing for other reasons $\left(\mathrm{T}_{3} ; 234 ; 4.31 \%\right)$, loss of job and unemployment $\left(\mathrm{T}_{4} ; 763\right.$; $14.06 \%)$, insufficient skills and education $\left(\mathrm{T}_{5} ; 349 ; 6.43 \%\right)$, lack of opportunities for further education $\left(\mathrm{T}_{6} ; 180 ; 3.32 \%\right)$, lack of financial needs for further education $\left(\mathrm{T}_{7} ; 197 ; 3.63 \%\right)$, unwillingness to get further education or training $\left(\mathrm{T}_{8} ; 337 ; 6.21 \%\right)$, oppression, pressure, blackmailing or threatening of adults at the work $\left(\mathrm{T}_{9} ; 81 ; 1.49 \%\right)$, unexcused absence or frequent absence of adults at work $\left(\mathrm{T}_{10} ; 28 ; 0.52 \%\right)$, high debt burden-inability to repay $\left(\mathrm{T}_{11} ; 140 ; 2.58 \%\right)$, attachment of earnings $\left(\mathrm{T}_{12} ; 96 ; 1.77 \%\right)$, threats posed by debt collectors $\left(\mathrm{T}_{13} ; 25 ; 0.46 \%\right)$, threats or pressure posed by national authorities $\left(\mathrm{T}_{14} ; 104 ; 1.92 \%\right)$, social pressure $\left(\mathrm{T}_{15} ; 307 ; 5.66 \%\right)$, and inability to provide care for children $\left(\mathrm{T}_{16} ; 91 ; 1.68 \%\right)$.

\subsection{Hypotheses and Statistical Procedures}

Each social threat mentioned above categorized respondents into those who are affected by the specific threat and those who are not. These categories determined for each threat were used as dependent variables in statistical testing of hypotheses. As factorial (independent) variables, we used the categories described above (gender, age, personal situation, family situation, and education). Our theoretical assumptions of these sociodemographic factors have a strong impact on the recognition of social threats, which led us to postulate five general hypotheses:

1. Gender has a significant influence on the recognition and feeling of social threats;

2. Age has a significant influence on the recognition and feeling of social threats;

3. Personal situation (occupation) has a significant influence on the recognition and feeling of social threats;

4. Family situation (condition) has a significant influence on the recognition and feeling of social threats; 
5. Achieved education has a significant influence on the recognition and feeling of social threats.

As we recognized and measured 5 factorial variables and 16 social threats, we can state $80(16 \times 5)$ relationships (statistical hypotheses) concerning the dependencies among the factors and threats. Each relationship could be formulated as the supposing of the factor $F_{1-5}$ significantly influences the feel of the threat $T_{1-16}$. Specific influence (statistical hypothesis- $\mathrm{H}$ ) could be identified by the code $\mathrm{HF}_{\mathrm{x}} \mathrm{T}_{\mathrm{y}}$. The whole matrix of statistical dependences (statistical hypotheses) $\mathrm{HF}_{1} \mathrm{~T}_{1}-\mathrm{HF}_{5} \mathrm{~T}_{16}$ results can found in Table 1.

Table 1. Table of the dependences of social threats on gender, age, personal situation, family situation, and education of the respondents (statistical dependencies $\mathrm{HF}_{1} \mathrm{~T}_{1}-\mathrm{HF}_{5} \mathrm{~T}_{16}$ ).

\begin{tabular}{|c|c|c|c|c|c|c|}
\hline Social Threats & $\begin{array}{c}\text { Frequency } \\
n \\
(f \text { in } \\
\text { Population })\end{array}$ & $\begin{array}{c}\text { Gender } \\
\left(\mathrm{F}_{1}\right) \\
p\end{array}$ & $\begin{array}{c}\text { Age } \\
\left(\mathrm{F}_{2}\right) \\
p\end{array}$ & $\begin{array}{c}\text { Personal } \\
\text { Situation } \\
\left(\mathrm{F}_{3}\right) \\
p \\
\end{array}$ & $\begin{array}{c}\text { Family } \\
\text { Situation } \\
\left(\mathrm{F}_{4}\right) \\
p \\
\end{array}$ & $\begin{array}{l}\text { Education }\left(\mathrm{F}_{5}\right) \\
p\end{array}$ \\
\hline $\begin{array}{l}\text { Unsatisfactory housing } \\
\text { conditions }\left(\mathrm{T}_{1}\right)\end{array}$ & $\begin{array}{c}309 \\
(5.70 \%) \\
\end{array}$ & 0.6283 & $0.0238^{*}$ & 0.0792 & $0.0013^{* *}$ & $<0.001 * * *$ \\
\hline $\begin{array}{l}\text { Loss of housing due to } \\
\text { lack of financial } \\
\text { funds }\left(\mathrm{T}_{2}\right)\end{array}$ & $\begin{array}{c}259 \\
(4.77 \%)\end{array}$ & 0.5332 & $<0.001^{* * *}$ & $<0.001^{* * *}$ & $<0.001^{* * *}$ & $<0.001^{* * *}$ \\
\hline $\begin{array}{l}\text { Loss of housing for } \\
\text { other reasons }\left(\mathrm{T}_{3}\right)\end{array}$ & $\begin{array}{c}234 \\
(4.31 \%) \\
\end{array}$ & 0.8978 & $<0.001^{* * *}$ & $0.0351 *$ & $<0.001^{* * *}$ & $<0.001^{* * *}$ \\
\hline $\begin{array}{c}\text { Loss of job and } \\
\text { unemployment }\left(\mathrm{T}_{4}\right)\end{array}$ & $\begin{array}{c}763 \\
(14.06 \%) \\
\end{array}$ & 0.8677 & $<0.001^{* * *}$ & $<0.001^{* * *}$ & $<0.001^{* * *}$ & $<0.001^{* * *}$ \\
\hline $\begin{array}{l}\text { Insufficient skills and } \\
\text { education }\left(\mathrm{T}_{5}\right)\end{array}$ & $\begin{array}{c}349 \\
(6.43 \%) \\
\end{array}$ & $0.0092 * *$ & $<0.001^{* * *}$ & 0.0293 * & $0.0470 *$ & $<0.001^{* * *}$ \\
\hline $\begin{array}{l}\text { Lack of opportunities } \\
\text { for further } \\
\text { education }\left(\mathrm{T}_{6}\right)\end{array}$ & $\begin{array}{c}180 \\
(3.32 \%)\end{array}$ & 0.0730 & 0.0141 * & 0.8501 & 0.2662 & 0.4933 \\
\hline $\begin{array}{l}\text { Lack of financial needs } \\
\text { for further } \\
\text { education }\left(\mathrm{T}_{7}\right)\end{array}$ & $\begin{array}{c}197 \\
(3.63 \%)\end{array}$ & $0.0323 *$ & $0.0015^{* *}$ & 0.0788 & $<0.001^{* * *}$ & 0.5223 \\
\hline $\begin{array}{l}\text { Unwillingness to get } \\
\text { further education or } \\
\text { training }\left(\mathrm{T}_{8}\right)\end{array}$ & $\begin{array}{c}337 \\
(6.21 \%)\end{array}$ & 0.0541 & $<0.001^{* * *}$ & $<0.001^{* * *}$ & 0.0221 * & 0.1593 \\
\hline $\begin{array}{l}\text { Oppression, pressure, } \\
\text { blackmailing or } \\
\text { threatening of adults at } \\
\text { work }\left(\mathrm{T}_{9}\right)\end{array}$ & $\begin{array}{c}81 \\
(1.49 \%)\end{array}$ & 0.2306 & 0.0455 * & 0.0807 & 0.2429 & 0.2985 \\
\hline $\begin{array}{l}\text { Unexcused absence or } \\
\text { frequent absence of } \\
\text { adults at work }\left(\mathrm{T}_{10}\right)\end{array}$ & $\begin{array}{c}28 \\
(0.52 \%)\end{array}$ & 0.8256 & 0.7306 & 0.5644 & 0.3343 & 0.1381 \\
\hline $\begin{array}{c}\text { High debt burden } \\
\text { (inability to repay) }\left(\mathrm{T}_{11}\right)\end{array}$ & $\begin{array}{c}140 \\
(2.58 \%) \\
\end{array}$ & 0.8767 & $0.0079 * *$ & 0.2551 & 0.1206 & 0.0127 * \\
\hline $\begin{array}{l}\text { Attachment of } \\
\text { earnings }\left(\mathrm{T}_{12}\right)\end{array}$ & $\begin{array}{c}96 \\
(1.77 \%) \\
\end{array}$ & 0.3786 & $0.0153^{*}$ & 0.3006 & 0.0679 & $0.0080 * *$ \\
\hline $\begin{array}{l}\text { Threats posed by debt } \\
\text { collectors }\left(T_{13}\right)\end{array}$ & $\begin{array}{c}25 \\
(0.46 \%) \\
\end{array}$ & 0.5967 & 0.2467 & 0.4400 & 0.1146 & $0.0389 *$ \\
\hline $\begin{array}{l}\text { Threats or pressure } \\
\text { posed by national } \\
\text { authorities }\left(\mathrm{T}_{14}\right)\end{array}$ & $\begin{array}{c}104 \\
(1.92 \%)\end{array}$ & $<0.001^{* * *}$ & 0.0164 * & $<0.001^{* * *}$ & 0.6178 & 0.4258 \\
\hline $\begin{array}{l}\text { Social pressure (from } \\
\text { the family, relatives, } \\
\text { close ones, etc.) }\left(\mathrm{T}_{15}\right)\end{array}$ & $\begin{array}{c}307 \\
(5.66 \%)\end{array}$ & $0.0264 *$ & $<0.001^{* * *}$ & $0.0064^{* *}$ & $0.0064^{* *}$ & 0.9551 \\
\hline $\begin{array}{l}\text { Inability to provide care } \\
\text { for children }\left(\mathrm{T}_{16}\right)\end{array}$ & $\begin{array}{c}91 \\
(1.68 \%) \\
\end{array}$ & 0.900 & $0.0034^{* *}$ & 0.3461 & $0.0212 *$ & 0.2791 \\
\hline
\end{tabular}

$n=$ count of threat observed in research sample; $f=$ threat frequency; $p=$ statistical significance of social threats depending on gender, age, personal situation, family situation, and education of the respondent: ${ }^{*} p \leq 0.05,{ }^{* *} p \leq 0.01,{ }^{* * *} p \leq 0.001$. 
For testing the statistical dependencies, we used a $\chi^{2}$ test of independence for $\mathrm{R} \times \mathrm{C}$ contingency tables (each factor $\times$ specific threat) $[19,20]$. In total, we calculated the dependencies of 80 contingency tables $\left(\mathrm{HF}_{1} \mathrm{~T}_{1}-\mathrm{HF}_{5} \mathrm{~T}_{16}\right)$, and the overall results of these tests are available in Table 1 . We also determined standard residuals in each contingency table. Standard residuals were statistically evaluated, and, for each cell of every table, the $z$ value was calculated $[20,21]$. These values allowed us to analyze each specific factor influence in each occurrence of each specific threat. In Table 1 only the summary $p$ of each of the $80 \mathrm{R} \times \mathrm{C}$ contingency tables is printed. The important findings of the detailed analysis are discussed in Section 3.1.

For the data collection and statistical analysis, The Social Survey Project (SSP) software [22] was used. For the analysis of dependence $\left(\chi^{2}\right.$ test of independence for $\mathrm{R} \times \mathrm{C}$ contingency tables, $z$ value), the internal statistical analytic engine of SSP was used.

\section{Results}

The relationships between each threat and factor can found in Table 1 . The results published in the table show a general influence map among the factors and the threats we measured.

\subsection{Findings}

The survey implies that the 35-44 age group does not feel at risk of unsatisfactory housing conditions $(p<0.01)$. Those who feel at risk are employees and, to the same extent, the groups that include pensioners, disabled pensioners, and women/men on parental leave $(p<0.05)$. The unemployed do not feel at risk. People living with their parents in an incomplete family without a family started on their own also feel at risk $(p<0.05)$. On the other end, individuals living with a family started on their own and with children $(p<0.001)$ do not perceive this risk. Individuals with vocational education feel at risk $(p<0.05)$, and individuals with primary education feel even more at risk $(p<0.01)$; on the contrary, individuals who received tertiary education feel less at risk than could be expected $(p<0.01)$.

Contrary to expectations, individuals in the 15-24 age group $(p<0.001)$ do not significantly feel the risk of losing their housing due to lack of financial funds. This threat is more perceived with people in the $45-54$ age category $(p<0.1)$. On the contrary, pupils/students do not feel to be at risk $(<0.001)$.

However, employees and pensioners, disabled pensioners, women/men on parental leave, and the unemployed feel at risk of this threat $(p<0.05)$. The threat is not reflected by individuals who live with their parents in a complete family without a family started on their own $(p<0.001)$, but, on the other hand, people living with their grandparents, foster parents, or in a children's home $(p<0.05)$, as well as those living alone $(p<0.01)$ feel this risk. It is admitted significantly more by people who live in an incomplete family started on their own and with children $(p<0.001)$. The loss of housing due to lack of financial funds is not a threat for people with primary education $(p<0.05)$, as well as to individuals with tertiary education $(p<0.01)$. On the other hand, it is reflected much more than we would have expect by individuals with vocational education $(p<0.001)$.

Loss of housing for other reasons (e.g., the termination of lease by the lessor, graduation, transitioning to another job, etc.) is perceived as risky for the 24-34 and 65+ age groups $(p<0.05)$. On the other hand, this risk is not considered as a threat by individuals in the $15-24$ age category $(p<0.001)$, i.e., pupils / students $(p<0.01)$, as well as those who live with their parents in a complete family without a family started on their own $(p<0.001)$. Loss of housing poses a threat for pensioners, disabled pensioners, and women/men on parental leave $(p<0.05)$, as well as those who live alone or with their partner unmarried $(p<0.001)$. On the contrary, individuals living in a complete family started on their own and with children do not feel to be significantly at risk $(p<0.05)$. As far as education achieved is concerned, individuals with vocational education feel significantly more at risk 
$(p<0.001)$, unlike individuals with primary education, who do not perceive this as a threat $(p<0.05)$.

The results of the survey tell us that individuals in the 15-24 age group $(p<0.001)$ do not perceive the loss of job and unemployment as a threat, unlike individuals of the 35-44 age group $(p<0.05)$, who feel at risk, as well as the 45-54, 55-64, and 65+ age groups, who feel more significantly at risk $(p<0.001)$. The risk is felt more significantly in the group of the employed, as well as unemployed individuals $(p<0.001)$, contrary to pupils/students and pensioners, disabled pensioner, and women/men on parental leave, who do not feel themselves to be at risk $(p<0.001)$. From the family situation perspective, this threat is not felt by individuals who live with their parents in a complete family without a family started on their own $(p<0.001)$. It is interesting that the threat is felt only by individuals who live in a family started on their own and with children $(p<0.01)$. As far as the category with the highest completed level of education is concerned, the threat was not felt by individuals in the category of primary education $(p<0.001)$; the only respondents who felt at risk are respondents with vocational education $(p<0.05)$.

Insufficient skills are significantly more frequently perceived by women $(p<0.01)$. This threat is also felt by the 15-24 age group $(p<0.05)$, unlike the 35-44 age group $(p<0.05)$ and $65+$ age group $(p<0.01)$, who do not feel threatened. This corresponds to pupils/students feeling at risk $(p<0.05)$; on the contrary, pensioners, disabled pensioners, and women $/$ men on parental leave do not perceive this as a threat $(p<0.05)$. Regarding the family situation, this threat is clearly felt by individuals living with their parents in an incomplete family without a family started on their own $(p<0.05)$. Individuals who live with their partner in a marriage do not feel to be at risk $(p<0.01)$. This threat is significantly felt by individuals with vocational education $(p<0.001)$; on the other hand, individuals with tertiary education do not perceive it $(p<0.01)$.

The survey has shown that the lack of opportunities for further education is felt by the 25-34 age group $(p<0.05)$, contrary to the 65+ age group $(p<0.05)$. This absolutely corresponds to the fact that the group of pupils/students feels at risk $(p<0.05)$, contrary to the group of pensioners, disabled pensioners, and women/men on parental leave $(p<0.05)$. Similarly, individuals living with their marriage partners do not perceive this as a risk $(p<0.05)$. Regarding the aspect of education, this risk was not manifested at all.

The lack of financial funds for further education is reflected more by women $(p<0.05)$. It is also felt to the same extent by the 15-24 age group $(p<0.05)$, contrary to the 55-64 age group $(p<0.01)$, as well as to individuals in the $65+$ age group $(p<0.01)$. The risk of insufficient financial funds is felt by the category of pupils/students $(p<0.01)$. Other categories did not report to feel at risk in this regard. Within the family situation, the following groups feel at risk: individuals living with their parents in an incomplete family without a family started on their own report to be at risk $(p<0.01)$; individuals living with their grandparents, foster parents, or in a children's home $(p<0.05)$; as well as those who live in an incomplete family started on their own and with children $(p<0.05)$. On the other hand, risk is not significantly felt by individuals living with their partner in marriage $(p<0.001)$. In the category of education, there was not any significant relation found.

The survey found that the unwillingness to be educated or trained is a threat significant for the 15-24 age group $(p<0.001)$; on the contrary, the $65+$ age group do not feel affected by this threat $(p<0.001)$. Thus, pupils/students feel to be the most at risk of this threat $(p<0.001)$, but this does not apply to the group of pensioners, disabled pensioners, and women $/$ men on parental leave $(p<0.001)$. There it was not proved to be a significant relation for the unemployed, which was expected. In the family situation category, a relation between the risk and the individuals living with their partner unmarried was identified $(p<0.05)$. On the other hand, individuals living with their partner in marriage do not feel threatened by this risk $(p<0.05)$. The threat is significantly reflected by the category of individuals with vocational education $(p<0.001)$, in contrast with individuals with tertiary education $(p<0.01)$. 
If we understand oppression, pressure, blackmailing, or the threatening of adults at work as a threat, then we can state that the threat was not identified as significant in relation to gender. Similarly, there was no statistically significant relation proved for any of the age categories, employment, or education. Only those individuals who live with their parents in an incomplete family without a family started on their own feel themselves to be at risk $(p<0.05)$.

As regards the threat implied by an unexcused or frequent absence of adults at work, there was not any significant relation with any of the observed categories identified.

A high debt burden represents a risk for individuals in the 25-34 age category $(p<0.05)$, and, on the other hand, individuals in the 15-24 age group do not feel at risk $(p<0.01)$, i.e., including pupils/students $(p<0.05)$, as well as those who live with their parents without a family started on their own in a complete family $(p<0.01)$. On the contrary, individuals who live with their partner not married $(p<0.05)$ feel at risk, as well as individuals with vocational education $(p<0.01)$.

The threat posed by the attachment of earnings is perceived by the 25-34 and 55-64 age groups (both $p<0.05)$, but it is not felt by the 15-24 age group $(p<0.05)$. There was no significant relation in the category of employment. The survey proved that individuals living alone feel at risk $(p<0.05)$, unlike individuals living with their parents in a complete family without a family started on their own, who do not feel at risk $(p<0.05)$. A significant feeling of being at risk is perceived again by individuals with vocational education $(p<0.01)$, but not by individuals with tertiary education $(p<0.05)$.

The threat posed by debt collectors is felt by the $24-34$ age group $(p<0.05)$, which corresponds to the threat of attachment of earnings. There was no significant relation found with the category related to personal or family situation. However, individuals with vocational education feel to risk $(p<0.05)$ which, again, corresponds with the previous threat posed by attachment of earnings.

Threats or pressure posed by national authorities are significantly felt by men $(p<0.001)$, particularly in the $45-54$ age group $(p<0.05)$. On the other hand, this threat is not perceived by the $15-24$ age group $(p<0.01)$. From the occupational point of view, the threat is important for the self-employed individuals $(p<0.001)$, in contrast with pupils/students, who do not feel at risk $(p<0.05)$. There was no significant relation found in the category related to family situation or education.

Threats implied by social pressure are felt more by women $(p<0.05)$. The survey identified a significant relation, especially to the $15-24$ age group $(p<0.001)$. On the contrary, this risk is not felt by individuals in the $45-54$ age group $(p<0.001)$. However, it is perceived by pupils/students $(p<0.01)$, and, on the contrary, not significantly perceived by employees $(p<0.01)$ which is, in both cases, related to the above-mentioned age category. Regarding family situation, this threat is significantly felt by those who live with their parents in an incomplete family without a family started on their own $(p<0.001)$. The threat is not perceived by individuals who live in a family started on their own and with children $(p<0.05)$. As regards the completed level of education, the survey did not prove any statistically significant relation.

The threat implied by the inability to provide care for children is significantly shown in the 35-44 age group $(p<0.01)$. On the other hand, this threat is not perceived by the $15-24$ age group $(p<0.05)$, i.e., pupils/students $(p<0.05)$. Regarding family situation, there was found the expected significant relation to individuals who live with their grandparents, foster parents, or in a children's' home $(p<0.01)$. On the contrary, as expected, those who live with their parents in a complete family without a family started on their own $(p<0.05)$ do not feel at risk. There was no significant relation found as regards to gender or the completed level of education.

\section{Discussion}

Scarpetta [6] estimates that $14 \%$ of current jobs could disappear due to automation in the next $15-20$ years, and a further $32 \%$ will probably change radically, as individual tasks 
will be automated. The rate of digital transformation increases, industrial robot orders tripled over the last ten years. Many people, as well as a number of working communities, are being pushed away due to globalization. There is still a digital gap in the approach to the new technologies, which results in creating inequalities between generations, genders, and in the social-economic sphere. Employment in the processing industry has dropped by $20 \%$ over the last two decades (1995-2015), whereas employment in services increased by $27 \%$ over the same period. This contributed to a polarization of the labor market - the proportion of low-skilled workers and the number of highly skilled jobs increased, whereas the level of medium-skilled jobs has decreased. In most OECD countries, the employment rate is growing. The proportion of women and older men is also growing. The percentage of highly skilled jobs has increased by $25 \%$ over the last 20 years. The advantage is that, thanks to new technologies, the difficult/monotonous and dangerous tasks can be automated to increase productivity, as well as the safety of workers.

These changes place demands on the modernization and modification of working procedures. For many workers, this means having to acquire new skills through further training. Those who feel at risk are mainly low-skilled workers. Regarding the respondents who have a fixed-term contract, $47 \%$ of them are at risk of losing their job [6]. Moreover, the financial pressure and insecurity have a negative impact on physical and mental health [23]. This means that we are transitioning into a system where skills need to be constantly updated to correspond to the changing needs.

Our survey has shown that, regarding frequency, the significant threat subjectively perceived is the loss of a job and unemployment (14.06\%), insufficient skills (6.43\%), unwillingness to be educated or trained $(6.21 \%)$, social pressure from the family, relatives, and loved ones (5.66\%), and unsatisfactory housing conditions (5.70\%) appear to be the most significant, but this does not diminish the severity of the other subjectively perceived threats among the differentiated groups. For this reason, they will be discussed below.

In terms of gender, it is clear that skills and education gaps are more common among women. They are also more vulnerable in terms of lack of financial resources for further education and social pressure (from family, relatives, loved ones, etc.). On the other hand, threats or pressure from state authorities are more strongly felt by men. It is clear that men are better able to withstand threats, but the gender gap is narrowing over time [24]. Our research generally confirms the trends in equality of living and working conditions and opportunities for men and women, but it also suggests that the situation in the Czech Republic cannot yet be considered completely gender equal. In particular, we consider the relationship of both genders to the threats of social oppression and coercion by state authorities to be remarkable. It appears that men are more often exposed to conflict resolution with state administration, while women build a wider and deeper social network.

The 15-24 age group, which includes pupils/students, feels at risk of insufficient skills, lack of financial funds for further education, an unwillingness to be educated or trained, and finally, by social pressure by the family, relatives, and close ones. In this category, partial or absolute security ensuing from the family situation is apparent. Many of these individuals cope with the lack of financial funds by getting temporary jobs in their free time or part-time jobs or occasional working activities. In 2018, there were $25.3 \%$ of employees with fixed-term contracts in the 15-24 age group [14]. In 2018, premature terminations of education (18-24 age group) were valued at $6.2 \%$. The most common reasons were the reluctance to study (30\%) and excessively demanding studies (22\%) [25].

In OECD countries, the participation of low-skilled adult workers in training is $40 \%$ lower than that of highly skilled workers. According to the OECD study [6], the situation of young people with lower than tertiary education has worsened. According to Eurostat [14], the 2018 unemployment rate in the 25-64 age group in the EU was $12.4 \%$ for individuals with preprimary education, $5.4 \%$ for individuals with secondary education, and $3.9 \%$ for individuals with tertiary education. 
The 25-34 age group perceives the threat of loss of housing for other reasons, e.g., lease termination by the leaser, graduation, transitioning to another job or starting a relationship, and experiences a lack of opportunities for further education, threat of high debt burden, as well as attachment of earnings. This is also related to the fact that this age group feels to be at the risk posed by debt collectors.

Individuals who live in an incomplete family started on their own and with children, people who live with their grandparents, foster parents, or in a children's' home, as well as individuals who live alone, feel significantly at risk by the risk caused by a loss of housing due to a lack of financial funds, as well as at risk due to insufficient financial funds for further education. Individuals who live unmarried with their partner consider being at risk of losing their housing for other reasons, e.g., lease termination by the leaser, graduation, transitioning to another job, etc., of unwillingness to be educated or trained, and of a high debt burden.

The survey confirmed the fact that incomplete families face a higher threat of insufficient financial funds. This reflected in the quality of housing, education, and, finally, it negatively affects the quality of relationships in the family and with close ones.

This age category is starting to build upon their work careers and their families that are linked to a flat/house purchase/lease and to buying furnishings, which needs a higher degree of financial funds. In 2018, men entered into marriage on average at the age of 32.2, and women at the age of 29.8 [13].

Changes on the labor market creates closer connections between education and development of working skills, as well as between education and quality of work in jobs. There is a continuously increasing pressure on improving the skills of the workforce, which demands high intensity of work effort. This results in many highly skilled men and women giving priority to a life without family obligations, or limiting their possibilities of quality job and work balance. In the EU in 2016, almost one third (32.5\%) of households were households consisting of one person [14]. According to Eurostat statistical reports [14], the lowest average age of women getting married for the first time was 24.8 years in Turkey, and the highest was 32.4 years in Denmark, the youngest average age of men was 27.8 years in Turkey, 34.6 years in Sweden. A permanent job does not guarantee a satisfying income and standard of living anymore. On the other hand, it risks creating a social category of poor employees who are on the threshold of the minimum income. According to Eurostat [14], the rate of poverty risk in EU countries in 2018 was $17.1 \%$ (men 16.4\%, women $17.8 \%$ ).

In the short term (1-2 years), one of the biggest risks and concerns is the effort to cover all costs. This applies to countries that have affected in the global economic crisis (e.g., in Greece, the risk is 70\%). According to the study, young people face the risk linked to housing and future perspectives. Increases in rent and property prices cause them, ensuring or keeping adequate housing is a serious risk for one third of respondents of the 20-34 age group [6]. On average, 60\% of parents who live with a child together in one household feel that their children are at risk of not achieving the same standard and comfort that they, as their parents, have [6].

The 35-44 age group perceives the threat of loss of job and unemployment, as well as threats ensuing from the inability to provide care for children. In the Czech Republic, the biggest changes in the population composition over the last ten years were in the 30-40 age group that consisted of individuals who were the key drivers of changes in demographic behavior. The representation of unmarried men aged 35-39 increased to $47.7 \%$, and of unmarried men aged 30-34 to $66.1 \%$. The ratio of unmarried women in the 30-34 and $35-39$ age groups increased identically in both cases to $49.9 \%$. In $2018,45 \%$ of divorced men and $43.4 \%$ of divorced women got married again [13].

The risk of unemployment or insufficient employment has increased more for men than for women over the last 10 years. Nevertheless, it is still higher for women. Moreover, women also work more often in less well paid jobs [6]. According to Eurostat [14], the employment rate in the 20-64 age group in the EU in 2018 was $73.2 \%$ (in 2008 it was 70.2\%). 
The employment rate of men has increased by $1.2 \%$ to $79 \%$ over the last 10 years, and the employment rate of women increased by $4.7 \%$ to $67.4 \%$. Grekousis [26] analyzed the spatiotemporal distribution of unemployment in the European Union, including the Czech Republic.

By weakening family ties, the participation of women in the labor market is rising and, at the same time, the divorce rate is also increasing. In 2016, there were approximately 2.2 million marriages and almost 1 million divorces in the EU (data from 27 countries except for Ireland) [14]. At the same time, the ratio of single parent households, i.e., incomplete families, is increasing. The cumulative effect of mothers' difficult living situation (low socioeconomic status of the family, inadequate housing conditions, social exclusion, weak family ties, low health literacy of the mother) can have a fatal impact on families with young children in extreme cases [27]. Moreover, the ratio of households on the officially determined poverty threshold is also increasing. This increases the probability that children in these households will grow up living in poverty. According to Eurostat [14], the ratio of households of the unemployed (18-59 age group) in 2018 was 9\% (men 9.5\%, women $8.6 \%$ ).

The 45-54 age group feels threatened by the loss of housing due to lack of financial funds, loss of job and unemployment and perceives the threat or pressure from national authorities. This generation often faces the problem of a combination of various obstacles, each of these being a significant limitation. It includes age, health condition, low skills, remote domicile, field-fragmented work experience or low flexibility, and high costs in relation to entering a new job [28]. Another issue contributing to the lack of financial funds is the ratio of divorced individuals aged $45+$ which is increasing over the long term, due to the high divorce rate, to a growing average length of marriage, and due to the marriages of elderly people. The share of divorced individuals in the population increases with age. In 2018, the largest number of divorced individuals was recorded in the 50-54 age group, both men $(25.3 \%)$ and women $(28.9 \%)$ [13].

The 55-64 age group feels at risk due to loss of job and unemployment, attachment of earnings, threatening, or pressure by national authorities. In 2018, there were 5.1\% employees with a fixed-term work contract in the 55-64 age group in the Czech Republic. In general, the older generation was threatened the most in the labor market. Individuals who lost their job have an opportunity for further education, such as retraining, workshops, or seminars. Of these, $20 \%$ of them do not participate in the education, since they think it is useless or that it does not ensure them getting another job. They get further education only if there is a certainty of getting a new job [25]. The barriers to further education are the following factors: situational, institutional, and personal [29]. The situational aspects, including a lack of time and financial costs, represent a barrier that prevents individuals from getting further education [30]. The institutional factors include a discrepancy if the offer of education, and the needs of the end beneficiaries. Personal barriers are individual attitudes, opinions, and expectations that play a motivational role regarding further education.

In the long term, the respondents feel the risk of financial security in old age $(72 \%$ on average). In most countries, more than a half of young respondents (18-29 age group) are aware of this fact. Young people are motivated to save money for their retirement, and, at the same time, they are aware of the financial pressures that are caused by population ageing. It is clear that most respondents of the 55-70 age group feel to be the most at risk $(82 \%)$ [6].

The survey has shown that the 65+ age group feels to be at risk of loss of housing for other reasons, e.g., lease termination by the leaser, lack of financial funds or transitioning to another job, or loss of job and unemployment. This generation are already receiving a pension, but if these financial funds are not sufficient, they often continue going to work or looking for jobs lacking a workforce. The population of seniors aged 65+ grew to 2.09 million in 2018. As regards to male pensioners, the married ones are prevalent $(72.0 \%)$, 
whereas there were slightly more widowed female pensioners, $(42.3 \%)$ than the married ones in 2018, due to the higher mortality rate of men [13].

Population ageing in OECD countries is accelerating. In the work process in 2018, there were 31 workers aged $65+$ per 100 workers still working. This ratio is to double by 2060 [31]. Most of the pension reforms focus on loosening the age requirements for receiving the pension benefit (e.g., Italy, the Netherlands), increasing pension benefits (Germany), widening of the pension coverage (e.g., Austria, France), or supporting private savings [31]. Enhancing private pensions is the most significant trend of the current reform of the pension systems. Many European countries perceive private pensions as a supplement to state pensions (e.g., in Belgium, the Czech Republic, Germany, Iceland, Ireland, Japan, Lithuania, Poland, Slovenia, and the United States, the coverage of voluntary pension plans (working or private) is more than $40 \%$ ) [31]. Thanks to financial funds and social services, people live more safely, healthier, and for longer, and yet, the OECD survey [6] shows that people are not satisfied with the social policy which is funded by $20 \%$ of the total economic production. Overall, we can conclude that, in the Czech Republic, the following threats subjectively perceived to be significant: loss of job and unemployment, insufficient skills, unwillingness to be educated or trained, social pressure, and unsatisfactory housing conditions. The groups who are the most at risk are individuals with primary education and with apprenticeship. In the population, women are more at risk, as well as the 25-34 and $45+$ age groups. On the contrary, complete functional families are able to face the threats better.

Although the OECD survey [6] overlaps with our survey only partially, we consider that the mutual compliance of both of the surveys conclusions is a confirmation of the validity of the findings. The threats consisting in the inability to cover all costs are linked, in the Czech Republic, to the threat of job loss, which was perceived as significant in our survey. According to the study, one third of the respondents in the 20-34 age group face the risk linked with the ensuring or maintaining adequate housing. In the Czech Republic, the aspect of the threat of housing loss proved to be significant for this generation. Furthermore, the survey confirmed the conclusions of the OECD study [6] as regards to the long-term threat of security for the elderly.

If we focus on the personal situation, we find that pupils/students are most subjectively threatened by their unwillingness to further their education and social pressure (from family, relatives, loved ones, etc.), and, to a lesser extent, by their lack of qualifications and education, given that education in the Czech Republic is compulsory (primary school), and free at all levels. Employees, who represent the second largest group in our research, feel threatened by the loss of housing due to the lack of financial resources, and by the loss of employment and unemployment. All of these concerns are understandable, and can be said to be shared by employees across the countries $[23,32,33]$. The self-employed feel threatened by pressure from state authorities. This threat is also not surprising, given the necessity and frequency of communication between the self-employed and the state apparatus. In the Czech Republic, this situation has long been criticized, and the conditions for obtaining and maintaining a trade are very complicated [34]. Pensioners and disabled pensioners feel at risk of losing their housing due to lack of funds or other reasons (e.g., landlord's termination of tenancy), which is related to the unfinished reform of the pension system $[35,36]$. Unemployment and loss of housing due to the lack of funds is also a strongly accentuated threat for the unemployed group due to the lack of jobs in many areas [37].

In terms of the family situation, people living with their parents in a single-parent family without a family of their own feel threatened by unsatisfactory housing conditions and more strongly by the loss of housing due to the lack of financial resources. This group is also threatened by the lack of funds for further education. This group also perceives a threat from social pressure (from their family, relatives, loved ones, etc.), and a lack of qualifications and education. This group emerges from our survey as the most vulnerable. The reason is that the lack of finances, especially for single mothers, brings 
many problems, such as ones related to housing, health, and the care and education of children. Most mothers feel that housing and, in particular, the limited space and environment in which they find themselves are more acute problems [38]. Individuals who live with their grandparents, foster carers, or in a children's' home feel threatened by the lack of financial resources to further their education, and an inability to provide care for their children. Public sector support can help ensure adequate care [39].

Those living alone or with an unmarried partner feel threatened by the loss of housing for other reasons, also by the inability to obtain further education or training. Financial problems are a significant aspect of housing stress and are also influenced and an impact on family and relationship functioning [40].

Those who start living on their own and with their own children feel threatened by the lack of skills and education, and even more by loss of employment and unemployment to be able to care for all members of their family. Education, long-term unemployment, and poverty are correlated. Long periods of unemployment, especially for young people, can have long-term effects on future employment and wages [41].

The survey results are also beneficial from an educational perspective. The most at-risk group appears to be people with apprenticeships, who subjectively perceive by a high risk of losing their housing due to the lack of financial resources and losing their housing for other reasons (e.g., termination of tenancy by the landlord, termination of studies, transfer to another job, etc.), as well as insufficient knowledge and skills. Other risks appear to be less significant from their point of view, namely job loss and unemployment, unsatisfactory housing conditions, and the threat associated with earnings. Next in the order is perceived the high debt burden and the threat posed by debt collectors. The risk of unsatisfactory housing conditions is felt by individuals with a vocational education, and even more so by individuals who only have the primary education. Many employers in different sectors offer further training to apprentices, even at considerable cost. The problem is that many apprenticeships are not perceived as beneficial, and the lack of skills development is undermining the performance of businesses and the economy as a whole [42]. As these workers are in high demand, there is an effort to develop better approaches to help improve their vocational education and training system [43].

\section{Conclusions}

As well as western countries, the Czech Republic is also facing new social risks. Globalization contributes to an increase in local unemployment, with supra-national companies moving to areas where costs are lower. Going for a cheaper workforce in various countries in the world enables, with regard to the time shift, a 24-h operation [44,45]. In the Czech Republic, as in other EU countries, there is a critical lack of workforce in the fields, such as care for the elderly, agriculture, or research and development. However, thanks to technologies, people also seize job opportunities in other cities or countries more often, and they can also work remotely thanks to a quality internet connection [45]. Moreover, the development of sustainable employment can be considered as one of the primary purposes in the government sector [46-49].

In line with Klimplova's conclusion [11], our study has shown an subjectively risk of increase in the number of unemployed and the subjectively perceived risk of skills obsolescence, with the associated risk of maintaining adequate employment. Furthermore, our study found a subjectively risk of under-qualification, and an unwillingness to educate or train. Similarly with research by the Sirius Foundation [12], our study confirmed the subjectively risk of loan accumulation and the extent of liabilities that do not match household income, and manifest themselves in foreclosures and threats from bailiffs. Together with often substandard housing conditions, they threaten the economic stability of households. Although in our research we did not measure the risk of poverty directly, our findings recognized groups of lone parents with children and households with multiple children as the most threatened, which is in compliance with both studies cited above, which recognized the risk of poverty in these groups. 
In our research we stated five general hypotheses derived from five recognized and theoretically expected socio-demographic factors influencing the subjective recognition and felt social threats. All these hypotheses could be considered to be confirmed and, as their detailed analysis of their inner relationships showed, each of them brought new knowledge concerning specific groups sensitive to certain social risks. The results of this research published in this paper support conclusions of the OECD study [6], and helps to analyze deeper consequences of risks or threats recognized by several groups of respondents. We expect the research of social threats can lead to specific kinds of support of the affected groups. The knowledge of perceived threats and the possibility to focus on these groups can help them overcome the barriers in community development [50], improve the programs for support of employment [51,52], change or adjust the support of housing [53], and, finally, help to remove the barriers in achieving further education [54].

The study published in this paper has several limitations. There are limits in the measurement of the threats (binomial measurement) and the consequences of the risks (the influence of risk in living conditions). There are also limits in the comparison of the results with the OECD's reported data due to the differences in the risk measurement and analysis. This is because we measured categorical data, and the $\chi^{2}$ test is non-parametric and was developed to analyze this kind of data; we were not able to provide the tests for the robustness designed to confirm the continuity of ratio data [19].

Further research of the subjective recognition of the social threats continues in the COVID-19 era and we are going to focus especially on the shift of threat recognition in the specific groups. The methods of social risks measurement are under consistent improvement, and focused on the inner structure of risk and consequences of the recognized risks.

Author Contributions: Conceptualization, L.S.T. and J.P.; methodology, J.P.; software, J.P.; validation, L.S.T., J.P. and H.P.; formal analysis, J.P.; investigation, L.S.T. and H.P.; resources, L.S.T., H.P.; data curation, J.P.; writing — original draft preparation, L.S.T.; writing—review and editing, L.S.T.; visualization, J.P. and H.P.; supervision, H.P.; project administration, H.P.; funding acquisition, J.P. All authors have read and agreed to the published version of the manuscript.

Funding: This research was funded by Internal grant agency of Palacký University, grant number IGA_CMTF_2020_007 Identification and research methods of medial, worldview, social and health factors influencing leisure and values.

Institutional Review Board Statement: Ethical review and approval were waived for this study, due to informed consent obtained from all subjects involved in the study.

Informed Consent Statement: Informed consent was obtained from all subjects involved in the study.

Data Availability Statement: The data presented in this study is available on request from the corresponding author.

Conflicts of Interest: The authors declare no conflict of interest.

\section{References}

1. Beck, U. Risk Society: Towards A New Modernity; Theory, Culture E Society; Sage Publications: London, UK; Newbury Park, CA, USA, 1992; ISBN 978-0-8039-8345-8.

2. Hall, D.; University of Western Ontario; Population Studies Centre. The Sociology of Risk and Social Demographic Change; Population Studies Centre, University of Western Ontario: London, ON, Canada, 2001; ISBN 978-0-7714-2315-4.

3. Saltkjel, T. Welfare Resources and Social Risks in Times of Social and Economic Change: A Multilevel Study of Material Deprivation in European Countries. Eur. J. Soc. Work 2018, 21, 639-652. [CrossRef]

4. Lavié, A.H.; Fernandez, A.I.L. New Social Intervention Technologies as a Challenge in Social Work: IFSW Europe Perspective. Eur. J. Soc. Work 2018, 21, 824-835. [CrossRef]

5. Gutjahr, E.; Heeb, J.-L. Social Assistance Trajectories in Switzerland: Do They Follow Discernible Patterns? Eur. J. Soc. Work 2016, 19, 570-585. [CrossRef]

6. OECD. Risks That Matter: Main Findings from the 2018 OECD Risks That Matter Survey; OECD Publishing: Paris, France, 2019.

7. Bonoli, G. New social risks and the politics of post-industrial social policies. In The Politics of Post-Industrial Welfare States; Armingeon, K., Bonoli, G., Eds.; Routledge: Oxfordshire, UK, 2006; pp. 3-26, ISBN 978-0-203-09952-0. 
8. Taylor-Gooby, P. New risks and social change. In New Risks, New Welfare: The Transformation of the European Welfare State; Taylor-Gooby, P., Ed.; Oxford University Press: Oxford, UK, 2004; pp. 1-27, ISBN 978-0-19-926726-2.

9. Keller, J. Koncept postindustriální společnosti a jeho slabiny [The Concept of Post-Industrial Society and its Flaws]. Sociologia 2011, 43, 323-337.

10. Taylor-Gooby, P.; Zinn, J.O. (Eds.) Risk in Social Science, 1st ed.; Oxford University Press: Oxford, UK, 2006; ISBN 978-0-19-928596-9.

11. Klimplová, L. Nová sociální rizika a reformní trendy evropských sociálních států v reakci na ně [New Social Risks and Reform Trends of European Welfare States in Reaction on These Risks]. Soc. Stud. 2010, 7, 23-43. [CrossRef]

12. Median; Sirius, N. Stav České Rodiny, Co Ji Chrání a Ohrožuje: Závěrečná Zpráva z Výzkumu [The State of the Czech Family, What Protects and Threatens It: Research Report]; Nadace Sirius: Praha, Czech Republic, 2016; ISBN 978-80-906468-1-0.

13. Czech Statistical Office Vývoj Obyvatelstva České Republiky. 2018. Available online: https:/ /www.czso.cz/csu/czso/vyvojobyvatelstva-ceske-republiky-2018 (accessed on 5 August 2021).

14. Eurostat Eurostat Database. Available online: https://ec.europa.eu/eurostat/web/main/data/database (accessed on 7 October 2020).

15. Dvořáková, Z. Řízení Lidských Zdrojů [Human Resource Management]; Nakladatelství C. H. Beck: Praha, Czech Republic, 2012; ISBN 978-80-7400-347-9.

16. Bryman, A. Social Research Methods, 4th ed.; Oxford University Press: Oxford, UK; New York, NY, USA, 2012; ISBN 978-0-19958805-3.

17. Black, T.R. Doing Quantitative Research in the Social Sciences: An Integrated Approach to Research Design, Measurement and Statistics; Sage: London, UK, 1999; ISBN 978-0-7619-5353-1.

18. Olecká, I.; Pospíšil, J. Human Values and the Feel of Social and Health Threats. Acta Missiologica 2021, $15,26-37$.

19. Sheskin, D. Handbook of Parametric and Nonparametric Statistical Procedures, 5th ed.; Chapman \& Hall/CRC: Boca Raton, FL, USA, 2011; ISBN 978-1-00-008327-9.

20. Agresti, A. An Introduction to Categorical Data Analysis; Wiley Series in Probability and Mathematical Statistics, 2nd ed.; Wiley: Hoboken, NJ, USA; Chichester, UK, 2007; ISBN 978-0-471-22618-5.

21. Azen, R.; Walker, C.M. Categorical Data Analysis for the Behavioral and Social Sciences; Routledge: New York, NY, USA, 2011; ISBN 978-1-84872-836-3.

22. Social Survey Project; ITTS: Olomouc, Czech Republic, 2018.

23. Kopasker, D.; Montagna, C.; Bender, K.A. Economic Insecurity: A Socioeconomic Determinant of Mental Health. SSM Popul. Health 2018, 6, 184-194. [CrossRef] [PubMed]

24. Lahtinen, H.; Sirniö, O.; Martikainen, P. Social Class and the Risk of Unemployment: Trends, Gender Differences and the Contribution of Education. Acta Sociol. 2020, 63, 303-321. [CrossRef]

25. Potočková, K. Osoby Ohrožené Sociálním Vyloučením a Dalši Profesní Vzdělávání: Postoje, Zkušenosti, Bariéry [Persons at Risk of Social Exclusion and Further Vocational Education: Attitudes, Experiences, Barriers]; Fond dalšího vzdělávání: Praha, Czech Republic, 2015.

26. Grekousis, G. Further Widening or Bridging the Gap? A Cross-Regional Study of Unemployment across the EU Amid Economic Crisis. Sustainability 2018, 10, 1702. [CrossRef]

27. Olecká, I.; Ivanová, K. Health Literacy of Primiparae in the First Six Months of Maternity: Review. Cent. Eur. J. Nurs. Midwifery 2016, 7, 494-503. [CrossRef]

28. Trlifajová, L.; Hurrle, J.; Kissová, B. Kdy se Práce Vyplatí? Analýza Ekonomických Motivacík Zaměstnání [When Does the Work Pay Off? Analysis of Economic Motivations for Employment]; Centrum pro společenské otázky—SPOT: Praha, Czech Republic, 2014.

29. Rabušicová, M.; Rabušic, L.; Šed'ová, K. Motivace a bariéry ve vzdělávání dospělých [Motivation and barriers in adult education]. In Učíme se po Celý Život? o Vzdělávání Dospělých v České Republice [Do We Learn for Life? on Adult Education in the Czech Republic]; Rabušicová, M., Rabušic, L., Eds.; Masarykova Univerzita: Brno, Czech Republic, 2012; pp. 97-112. ISBN 978-80-210-5859-0.

30. Žáčková, H. Co brání dospělým v účasti na dalším vzdělávání? [What prevents adults from participating in further education?]. ProFuturo Bull. Pro Podporu Rozv. Lidských Zdrojů 2009,1,11-12. Available online: http://old.nvf.cz/profuturo/2009_1/2009_1.pdf (accessed on 5 August 2021).

31. OECD. Pensions at a Glance 2019: OECD and G20 Indicators; OECD Publishing: Paris, France, 2019; ISBN 978-92-64-78791-9.

32. De Cuyper, N.; De Witte, H.; Vander Elst, T.; Handaja, Y. Objective Threat of Unemployment and Situational Uncertainty During a Restructuring: Associations with Perceived Job Insecurity and Strain. J. Bus. Psychol. 2010, 25, 75-85. [CrossRef]

33. Glavin, P.; Young, M. Insecure People in Insecure Places: The Influence of Regional Unemployment on Workers' Reactions to the Threat of Job Loss. J. Health Soc. Behav. 2017, 58, 232-251. [CrossRef] [PubMed]

34. Buno, M.; Nadanyiova, M.; Hraskova, D. The Comparison of the Quality of Business Environment in the Countries of Visegrad Group. Procedia Econ. Financ. 2015, 26, 423-430. [CrossRef]

35. Vavrejnová, M.; Belabed, E.; Wörister, K. Pension Reform in the Czech Republic: Present Situation and Future Prospects (A Comparison with Austria). Prague Econ. Pap. 2004, 13, 237-259. [CrossRef]

36. Louzek, M. Pension System Reform in Central and Eastern Europe. Post Communist Econ. 2008, 20, 119-131. [CrossRef]

37. Wiemers, E.E. The Effect of Unemployment on Household Composition and Doubling Up. Demography 2014, 51, 2155-2178. [CrossRef] [PubMed]

38. Mihaela, G.; Busuioc, M. Maternal Single-Parent Family in Social Risk Situation. Psychosoc. Behav. Charact. 2016, 9, 97-108. 
39. Miller, C.M.; Gruskin, S.; Subramanian, S.V.; Rajaraman, D.; Heymann, S.J. Orphan Care in Botswana's Working Households: Growing Responsibilities in the Absence of Adequate Support. Am. J. Public Health 2006, 96, 1429-1435. [CrossRef] [PubMed]

40. Conger, R.D.; Conger, K.J.; Martin, M.J. Socioeconomic Status, Family Processes, and Individual Development. J. Marriage Fam. 2010, 72, 685-704. [CrossRef] [PubMed]

41. Bejaković, P.; Mrnjavac, Ž. The Danger of Long-Term Unemployment and Measures for Its Reduction: The Case of Croatia*. Econ. Res. Ekon. Istraživanja 2018, 31, 1837-1850. [CrossRef]

42. Gambin, L.; Hogarth, T. Employers and Apprenticeships in England: Costs, Risks and Policy Reforms. Empirical. Res. Voc. Ed. Train 2017, 9, 16. [CrossRef]

43. Sappa, V.; Aprea, C. Conceptions of Connectivity: How Swiss Teachers, Trainers and Apprentices Perceive Vocational Learning and Teaching Across Different Learning Sites. Vocat. Learn. 2014, 7, 263-287. [CrossRef]

44. Beck, U. Beyond Class and Nation: Reframing Social Inequalities in a Globalizing World1. Br. J. Sociol. 2007, 58, 679-705. [CrossRef] [PubMed]

45. European Commission Directorate-General for Communication. Reflection Paper on Harnessing Globalisation; Publications Office of the European Union: Brussel, Belgium, 2017; ISBN 978-92-79-68226-1.

46. Bolvig, I.; Jensen, P.; Rosholm, M. The Employment Effects of Active Social Policy; Social Science Research Network: Rochester, NY, USA, 2003.

47. The Research, Development and Innovation Council. Národní Politika Výzkumu, Vývoje a Inovací České Republiky 2021+ [National Research, Development and Innovation Policy of the Czech Republic 2021+]; The Research, Development and Innovation Council: Praha, Czech Republic, 2020.

48. Wu, Y.; Wu, Y.; Wu, S. Development and Challenges of Social Enterprises in Taiwan-From the Perspective of Community Development. Sustainability 2018, 10, 1797. [CrossRef]

49. Burgoon, B.; Dekker, F. Flexible Employment, Economic Insecurity and Social Policy Preferences in Europe. J. Eur. Soc. Policy 2010, 20, 126-141. [CrossRef]

50. Ledwith, M.; Ledwith, M.; Campling, J. Community Development: A Critical Approach; Policy Press: Bristol, UK, 2005; ISBN 978-1-86134-696-4.

51. Riggle, R.J.; Edmondson, D.R.; Hansen, J.D. A Meta-Analysis of the Relationship between Perceived Organizational Support and Job Outcomes: 20 Years of Research. J. Bus. Res. 2009, 62, 1027-1030. [CrossRef]

52. Bynner, J.; Parsons, S. Social Exclusion and the Transition from School to Work: The Case of Young People Not in Education, Employment, or Training (NEET). J. Vocat. Behav. 2002, 60, 289-309. [CrossRef]

53. Parsell, C.; Marston, G. Beyond the 'At Risk' Individual: Housing and the Eradication of Poverty to Prevent Homelessness. Aust. J. Public Adm. 2012, 71, 33-44. [CrossRef]

54. Goto, S.T.; Martin, C. Psychology of Success: Overcoming Barriers to Pursuing Further Education. J. Contin. High. Educ. 2009, 57, 10-21. [CrossRef] 